\title{
Landfill Siting Evaluation Using GIS and Multi-Criteria Decision-Making Method: A Case Study: Dammam Municipal Solid Waste Landfill
}

\author{
Nora Al Khaldi, Firdos Almadani, Sara Ouerghi \\ Department of Geography and GIS, Faculty of Arts \& Humanities, King Abdulaziz University, Jeddah, Saudi Arabia \\ Email: Fmalmadani@kau.edu.sa
}

How to cite this paper: Al Khaldi, N., Almadani, F. and Ouerghi, S. (2021) Landfill Siting Evaluation Using GIS and Multi-Criteria Decision-Making Method: A Case Study: Dammam Municipal Solid Waste Landfill. Journal of Geographic Information System, 13, 508-522.

https://doi.org/10.4236/jgis.2021.134028

Received: January 19, 2021

Accepted: August 6, 2021

Published: August 9, 2021

Copyright $\odot 2021$ by author(s) and Scientific Research Publishing Inc. This work is licensed under the Creative Commons Attribution International License (CC BY 4.0).

http://creativecommons.org/licenses/by/4.0/

(c) (i) Open Access

\begin{abstract}
Waste landfills are a prominent global issue that does not concern a country without the other because of its long-term effects especially in the environmental aspect. As these pose an environmental threat to water, air and soil; and directly affect human life and health. Accordingly, this research uses the integration of Geographic Information Systems (GIS) and Multi-Criteria Decision-Making (MCDM) approaches to assess the location of the municipal solid waste dump in Dammam, which was established in (2000AD) twenty years ago, due to the lack of recent studies assessing the current status of the landfill and whether it is in a suitable location and keeps pace with the population and urbanization increase in the region. For this purpose, the researchers are using the tools and techniques of GIS to evaluate eight criteria on the study area. The required standards were directed to the landfill site and transformed into maps that represent the most important economic, social, environmental, geological, geomorphological and Public Acceptance standards. These standards have been processed using the tools of spatial and statistical analyses. Analytic Hierarchy Process (AHP) is implemented in geographical information system for building the suitable cartographic model, and thus allowed to determine the suitable degree of Dammam municipal solid waste landfill site in light of the study criteria. The study concluded that the current landfill site achieves a good degree of suitability, as it achieved $63 \%$ measured against the quality standards set by the study, and that the current landfill site conforms to most of the criteria in this study to a good degree. But it violates two standards, which are distance from wells standard and distance between landfill and the center of waste generation standard.
\end{abstract}

\section{Keywords}

Landfill Site, Criteria Weights, GIS, Analytic Hierarchy Process (AHP) 


\section{Introduction}

The explosive growth of the urban population and economic progress in recent years has increased the responsibility of governments to reduce the negative impact caused by this growth. One of the most devastating effect is the alarming increase in environmental pollution and the increase in waste per capita in the recent years. The increasingly alarming factors therefore require significant innovation to improve the solid waste management (SWM) [1].

Waste management is a significant issue, it is a significant concern to governments since such issues might not only have an environmental effect but could also lead to health complications to the population, which could also spread to neighboring countries. Several inter-state agreements have been concluded between countries to reduce waste risk since it is a risk that is globally recognized, one of the most important international agreements is the Basel Convention on the Control of Transboundary Movements of Hazardous Wastes and their Disposal, also defined simply as the Basel Convention, which was adopted on 22 March 1989 by the Conference of Plenipotentiaries in Basel, Switzerland that Saudi Arabia joined in 1990. The overarching objective of the Basel Convention is "to protect human health and the environment against the adverse effects of hazardous wastes. Its scope of application covers a wide range of waste defined as 'hazardous wastes' based on their origin, composition and their characteristics in addition to two types of wastes defined as 'other wastes'household waste and incinerator ash" [2].

Industrial organizations and urban areas' solid wastes engender serious environmental problems. Various techniques are being used to tackle solid waste management. Such techniques include thermal treatment, landfilling, recycling, and biological treatment [3].

One of the primary methods of municipal solid waste disposal is sanitary landfill. Traditionally this is defined as "an engineered method of disposing solid wastes on land in a manner that protects the environment by spreading thin layers of waste and compacting it to smaller particles in volume which is later covered with soil by the end of each working day" [4].

Given the situation in Kingdom of Saudi Arabia, we found rate of waste generation in Saudi Arabia is one of the highest in the world with $1.5 \mathrm{KG}$ /day per capita while the global average which is $74 \mathrm{KG} /$ day for person [5]. Many factors contribute to such extreme rate like social customs and lack of awareness. This made waste management a major challenge for the government in preserving the environment and a serious threat towards the public health, especially in the three major cities Riyadh Jeddah and Dammam.

Thus, the need for a research combining GIS with Method of (MCDM) to evaluate Municipal Solid Waste landfill site in Dammam city is critical.

So as to achieve research objective, ten criteria based on Basel Convention have been considered as data for the suitability model, analytic hierarchy process (AHP) technique of multi-criteria decision-making (MCDM) has been used in this study to weight the criteria, (AHP) technique was used in many studies in 
many fields and it has proven its effectiveness and success, and in our study fields, it was used in many studies, for example [6] [7] [8]. This study aimed to evaluate Municipal Solid Waste (MSW) landfill site in Dammam city combining GIS with Method of (MCDM).

\section{Geographical Setting}

The study area located in the Eastern Region, which is the largest geographical region of Saudi Arabia. It has an area of $778,479 \mathrm{~km}^{2}$ that represents about $26 \%$ of the Kingdom's total area. The Eastern Region is divided into 11 governorates, which are Dammam, Khobar, Al-Hasa, Qatif, Abqaiq, Jubail, Hafr Al-Batin, Ras tanura, Nairyah, Khafji, and Al Elyah. Dammam is a coastal city located on the Arabian Gulf (latitude $26.43^{\circ}$ North and longitude $50.10^{\circ}$ east). It is the capital of the Eastern Region and has King Abdul-Aziz port, which is the main port on the Arabian Gulf.

Dammam's Municipal Solid Waste is located in the Southwestern Dammam (Figure 1), near Dammam-Abqaiq Highway (latitude 26.16 north and longitude

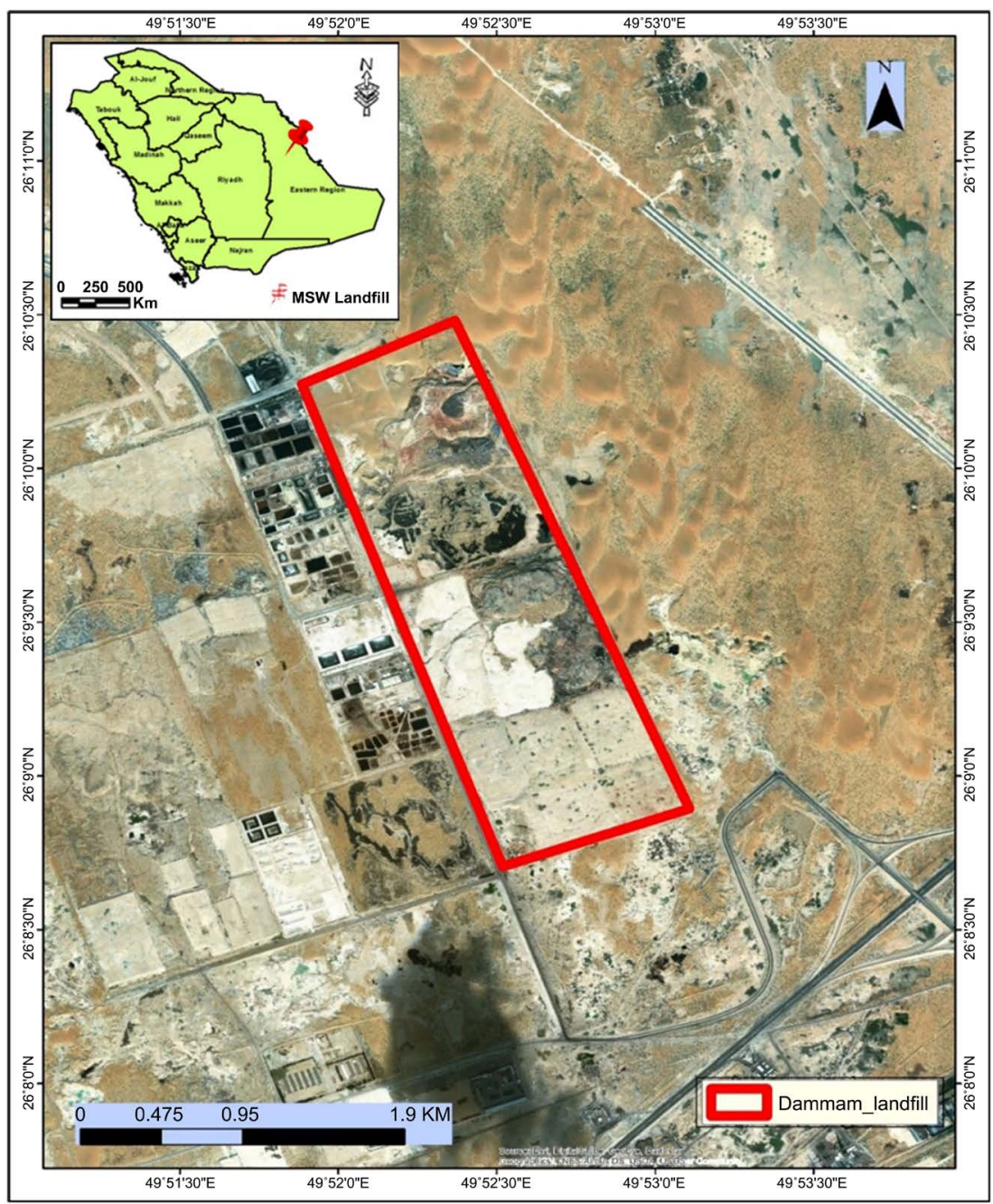

Figure 1. Study area location. 
49.86 east). It was established in the year 2000 covering an area of $8 \mathrm{~km}^{2}$. It is used to collect waste from Qatif and the metropolis locations of Dammam or Greater Dammam including Dammam, Khobar and Dhahran.

\section{Materials and Methods}

GIS's ultimate power is in its ability to perform analysis. Problems are modeled geographically in a process called spatial analysis. Results are derived by computer processing, followed by exploration and analysis of the results. This type of analysis has proved to be of high effectiveness when the objectives are: to evaluate geographic suitability of certain locations for specific purposes, estimate and predict outcomes, interpret and understand changes, detect important patterns hidden in the information presented, etc. and much more.

In this study, the researchers are in the process of evaluating the site in regard to the solid waste landfill of the Municipality of Dammam. GIS and analytical tools are used to prepare maps that cover the most important criteria in the area studied, with reference to expert opinion. The study adopts the workflow shown in Figure 2.

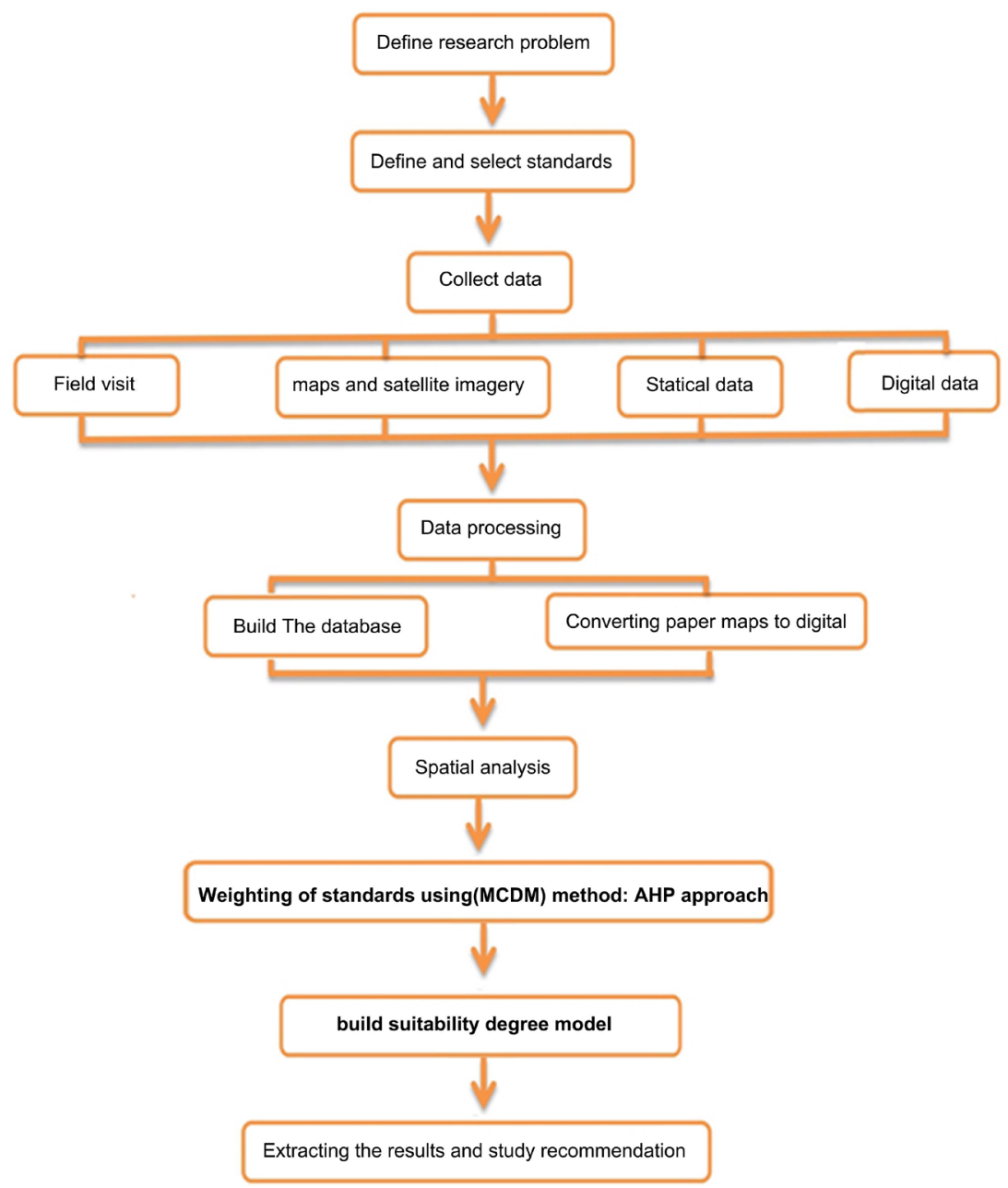

Figure 2. Work flow chart. 


\subsection{Define and Select Criteria}

To continue to appropriate landfill location, eight criteria as layer map criteria were made up based on GIS spatial analysis tools for studied zone. These were urban area layers, airports, slope, roads soil types, groundwater depth, geological formations, in accordance with environmental, socio-economical and Geological and geomorphological component for the choice of landfill location.

The data for this research was obtained from official government authorities as shown in Table 1 which summarizes the main sources of data.

\subsection{Criteria Restriction}

The acceptable distance from landfill sites is determined on the basis of government regulations, eventual environmental risks, and also public health and economical evaluation for each criterion [9] [10]. The development of specific geographical features was done through buffer zones by GIS spatial analysis software around each criterion. The creation of buffer zones hinged on criteria and requirements of the Regional Center for Training and Technology Transfer in the Arab Countries affiliated to the Basel Convention in Egypt (BCRC). This is crucial in determining the distance from each feature to the specified criteria. Restricted criteria and suggested buffer values for the study area were presented in Table 2.

Table 1. Restricted criteria and recommended buffer values for the study zone.

\begin{tabular}{cc}
\hline Data & Sources \\
\hline Topographic map of Dammam & Geological Survey Authority \\
Geological map of Dammam & Geological Survey Authority \\
Saudi provinces map & General Commission for Survey \\
Roads network map & Ajaji maps \\
Governate of Eastern Region & Eastern Region Municipality \\
Coordinates of the landfill site & Eastern Region Municipality \\
Satellite Image & United States Geological Survey (USGS) web site \\
Coordinates of Dammam airports & Eastern Region Municipality \\
\hline
\end{tabular}

Table 2. Restricted criteria and suggested buffer values for the study area.

\begin{tabular}{|c|c|c|}
\hline Standards & Criteria & Restricted Criteria (Buffer Zone) \\
\hline \multirow{3}{*}{ Environmental } & Ground water & $>200 \mathrm{~m}$ \\
\hline & Distance from wells & $>25 \mathrm{~km}$ \\
\hline & Distance from airports & $>9.5 \mathrm{~km}$ \\
\hline \multirow[t]{3}{*}{ Social and economic } & $\begin{array}{l}\text { Distance between landfill and } \\
\text { the center of waste generation }\end{array}$ & $\begin{array}{l}\text { The maximum distance is } 50 \mathrm{Km} \text { or } \\
\text { maximum time taken per trip for } \\
\text { assembly vehicles } 30-45 \mathrm{~min}\end{array}$ \\
\hline & Property boundary & $>500 \mathrm{~m}$ \\
\hline & Distance from primary highways & $>500 \mathrm{~m}$ \\
\hline Geological and & Soil & Soil should have low permeability \\
\hline geomorphological & Slope & $5 \%$ is perfect \\
\hline
\end{tabular}




\subsection{Sub-Criteria Rating Values}

Each criterion was classified into sub-criteria, then allocated a suitability score (values from zero to six) [2]. Several steps were involved in determining the ranking value for each criterion and sub-criteria. These include buffer, clip, extract, overlay, proximity, convert, reclassify and map algebra using GIS spatial analyst tools. Appendix 1 (Table A1) presents the sub-criteria buffer zone and rating values for the input layer.

In this research, sub-criteria rating value of 0 corresponds to the nearest restricted area from the landfill. A rating value of 6 , however, was assigned to the best zone. The suitability index for the classes, from 0 to 6 , was graded in accordance with the degree of the slope and the elevation distribution. Buffer zones and suitability index maps figure are in Figure 3 and Figure 4 . This can be

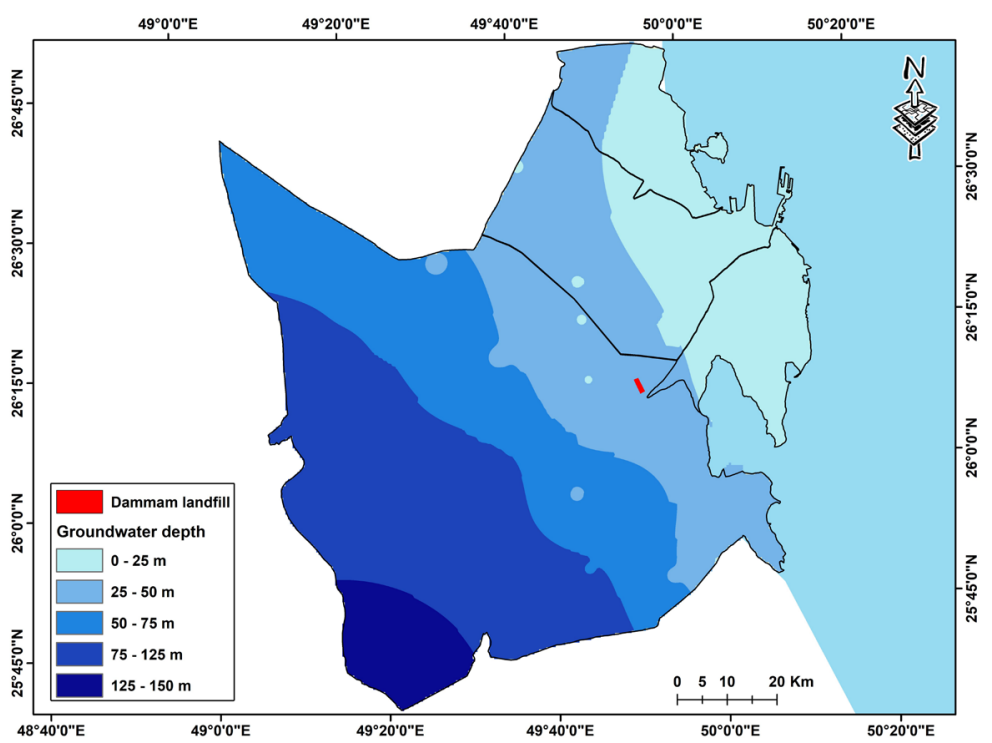

(A)

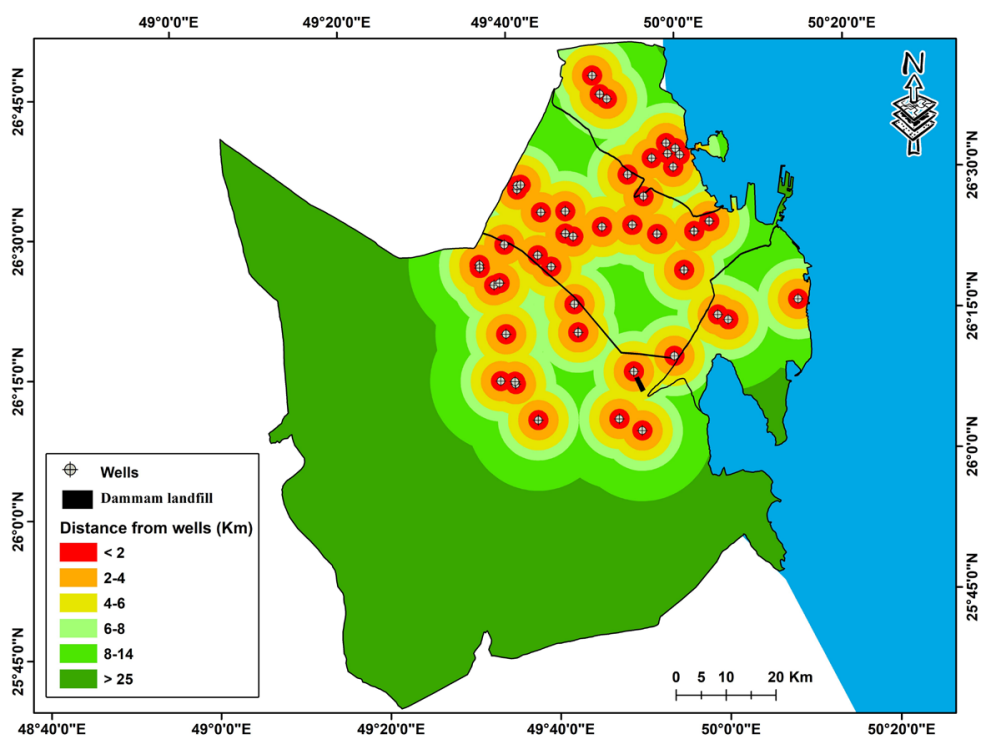

(B) 


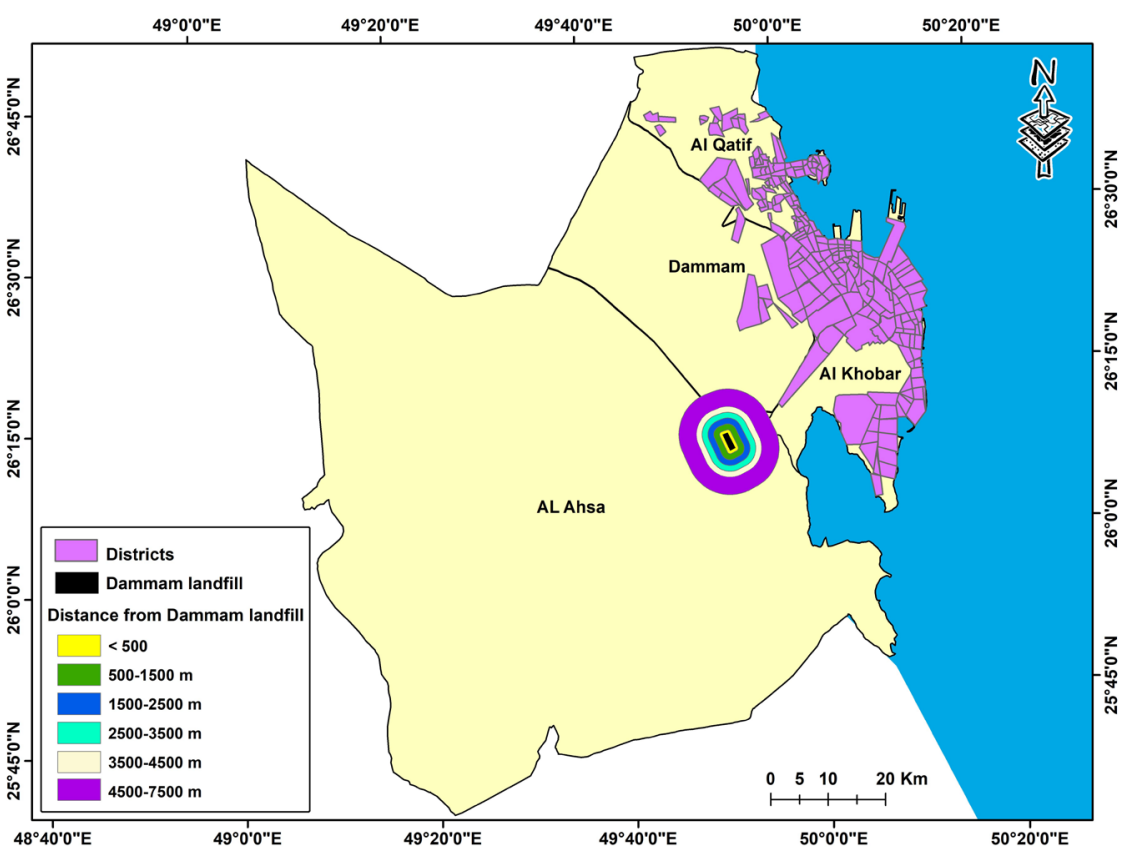

(C)

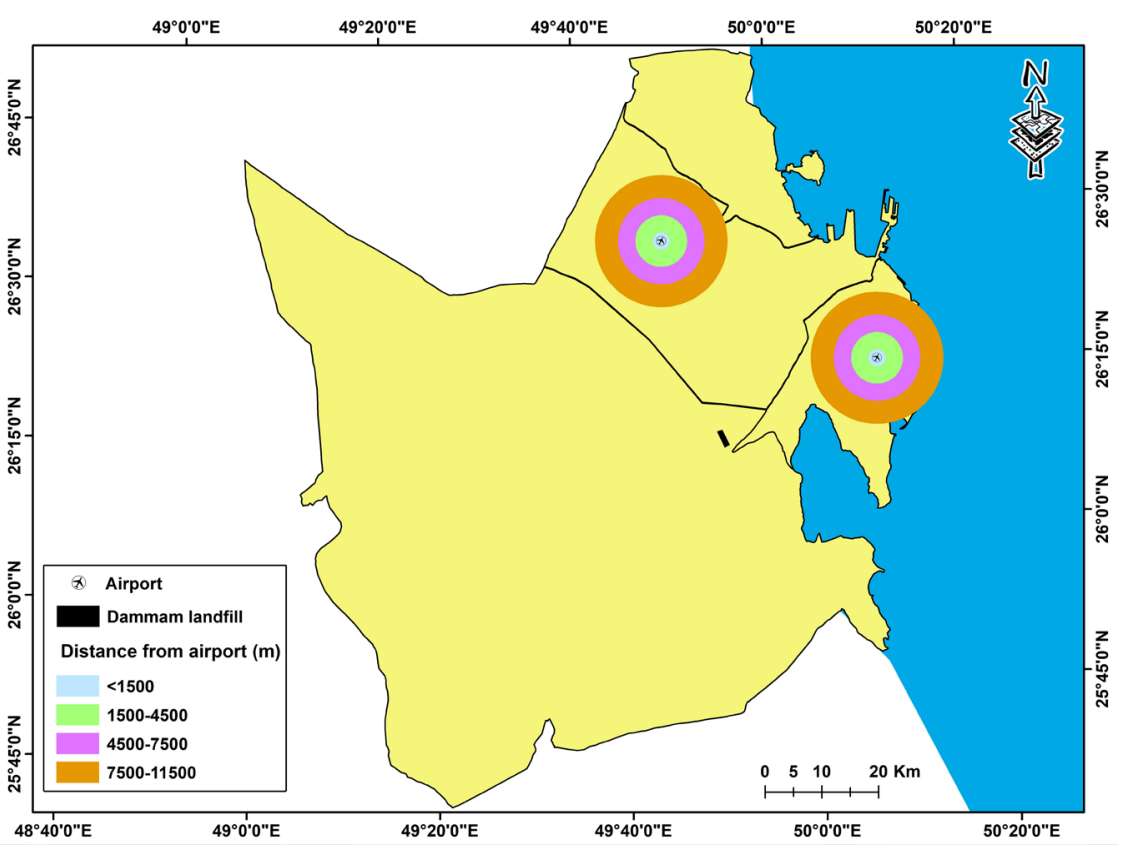

(D)

Figure 3. Buffer zones and suitability index maps: (A) Groundwater depth; (B) Distance from wells; (C) Distance from property boundary; (D) Distance from airports.

clearly seen in the sub-criteria "Slope" which consists of seven classes less than 0.5, equal to 0.6, 0.7, 0.9, 1.1, 1.2 and 1.5 as depicted in Figure 4(C).

\subsection{The Analytic Hierarchy Process (AHP) Approach for Multi-Criteria Decision-Making}

Pairwise comparison is applied in the matrix for all criteria depending on the 
priority of the significance importance of one criterion over another using a numerical scale of nine points, as listed in Table 3. According to [11], the scale ranges from one to nine, with one implying an equal weight of the two criteria. Conversely, the number nine implies the extreme importance of one element over the other in the pairwise matrix.

The comparative criteria values fill the upper triangular matrix. The upper reciprocal values, however, fill the lower one [12] [13]. To calculate the eigenvalue, the value for each criterion in each column in the same row in the pairwise matrix is multiplied. The determination of the priority vector (Pri) is completed by normalizing the eigenvalue to one [11] as follows:

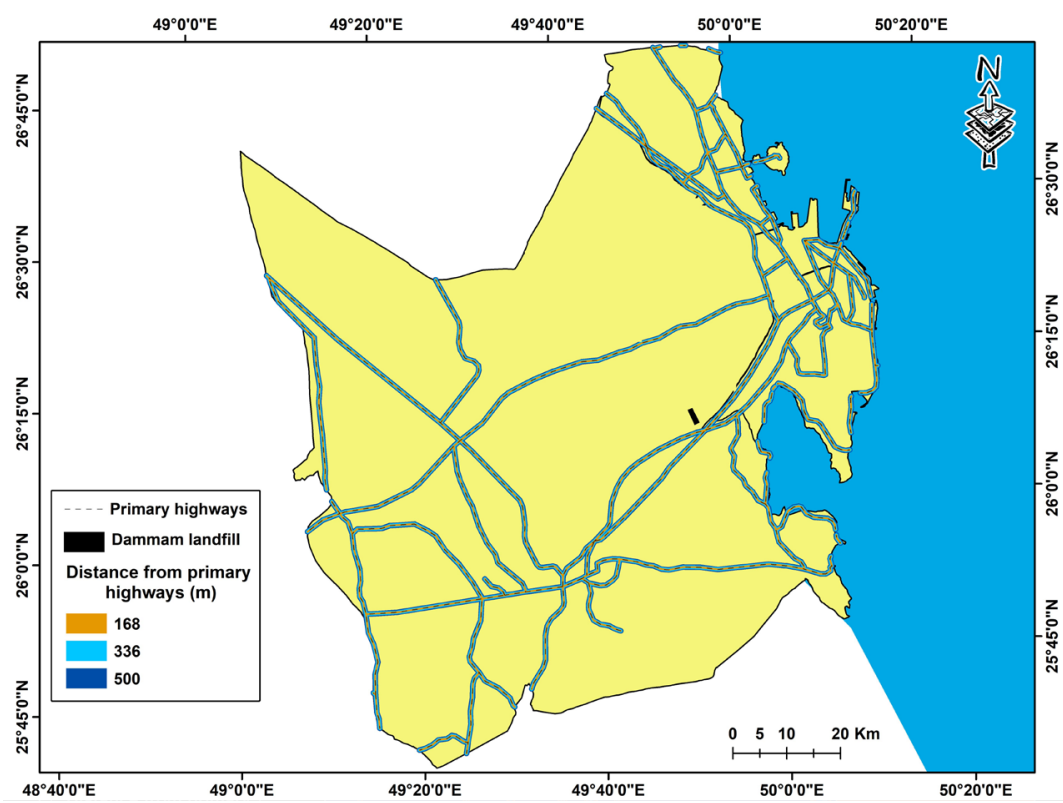

(A)

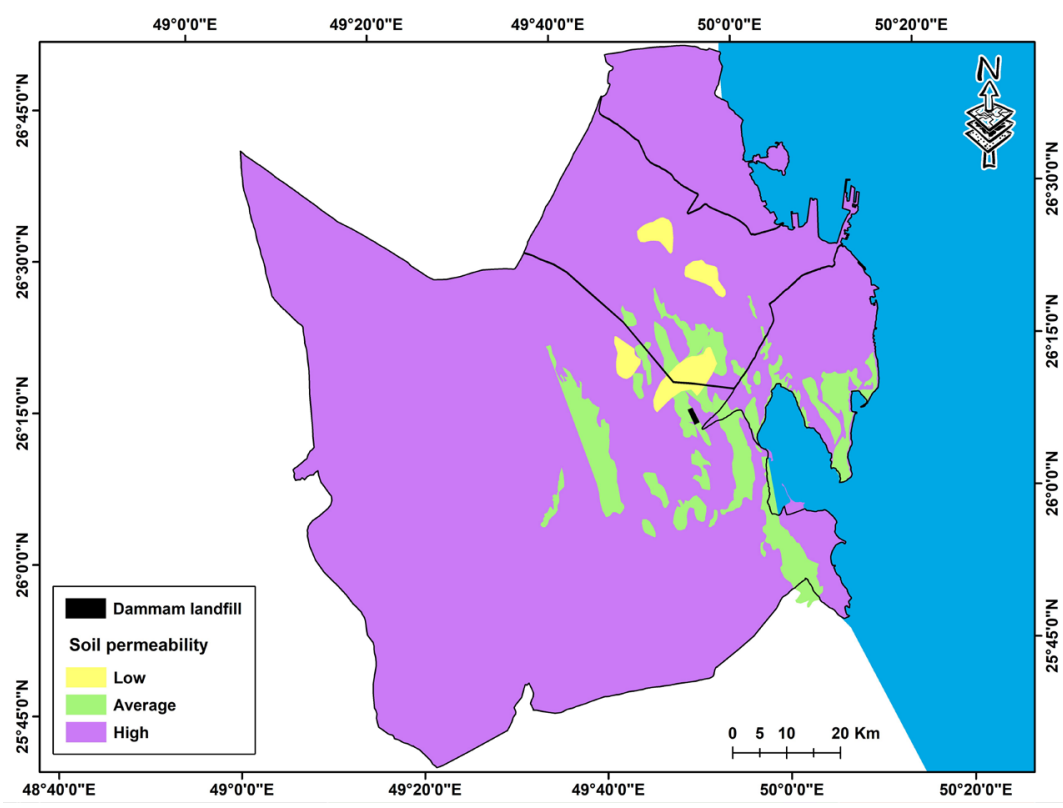

(B) 


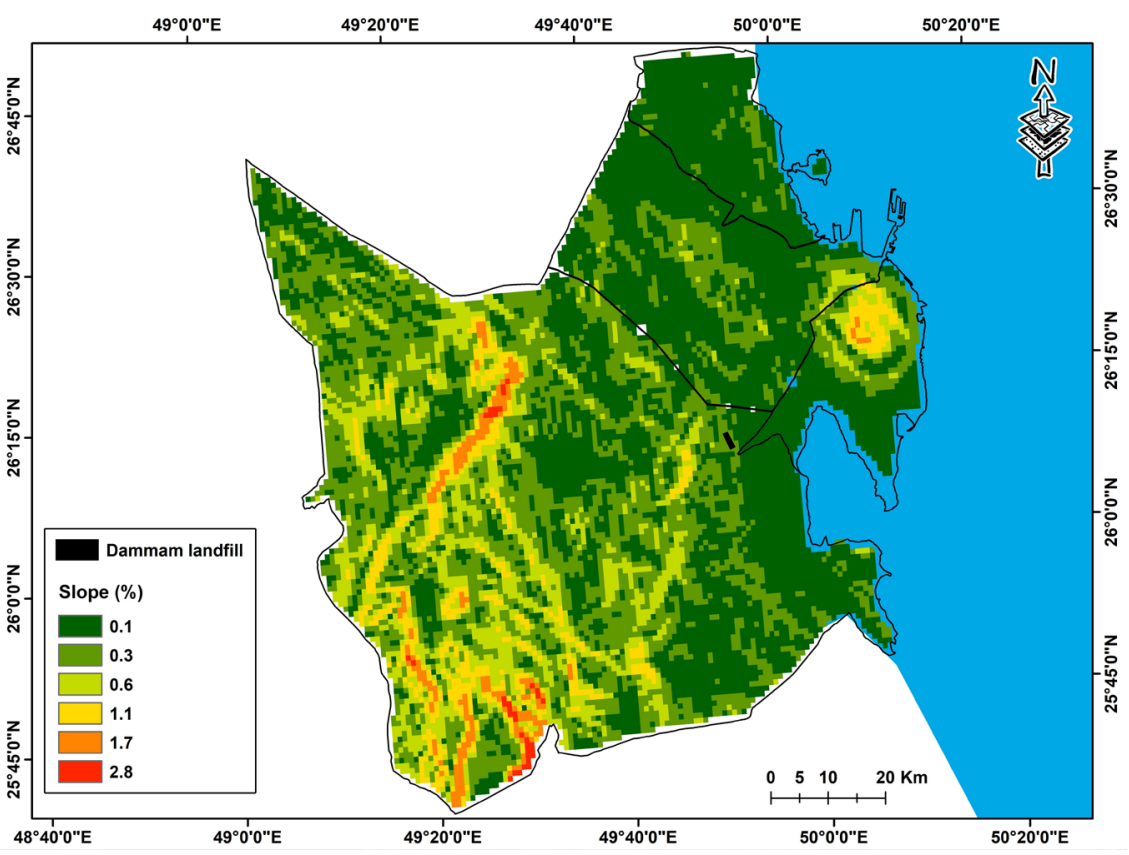

(C)

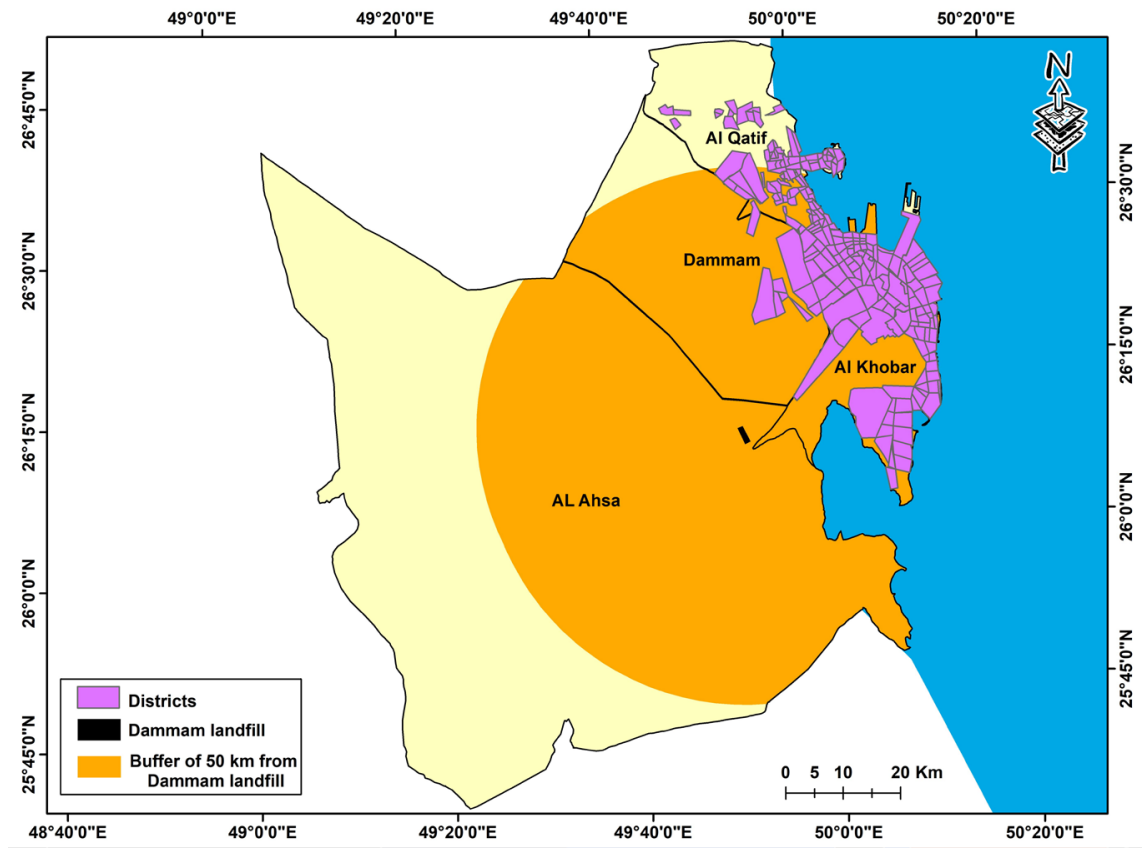

(D)

Figure 4. Buffer zones and suitability index maps: (A) Distance to Primary Highways; (B) Permeability; (C) Slope; (D) Distance from waste generation sources.

$$
\operatorname{Pri}=\frac{E g_{i}}{\sum_{i=1}^{n} E g_{i}}
$$

where $E g_{i}=$ eigenvalue for the row $(i)\left(E g_{i}=\left(a_{11} \times a_{12} \times a_{13} \ldots \times a_{1 n}\right)^{1 / n}\right)$;

$n=$ number of elements in matrix row $(i)$.

The consistency index (CI) is calculated using the equation 
Table 3. The fundamental scale of (AHP) method.

\begin{tabular}{cc}
\hline Intensity of importance & Definition \\
\hline 1 & Equal importance \\
2 & Weak \\
3 & Moderate importance of one factor over another \\
4 & Moderate plus \\
5 & Strong importance \\
6 & Strong plus \\
7 & Very strong importance \\
8 & Very, very strong \\
9 & Extreme importance \\
\hline
\end{tabular}

$$
\mathrm{CI}=\frac{\lambda_{\max }-n}{n-1}
$$

with reference to [11]. The maximum lambda $\left(\lambda_{\max }\right)$ is the result of the summation of products between each criteria of priority vector. The sum of columns of the reciprocal matrix is shown in the following formula:

$$
\lambda_{\max }=\sum_{j=1}^{n}\left[w_{j} \sum_{i=1}^{m} a_{i j}\right]
$$

where, $W_{j}$ is the weight value for each criterion corresponding to the priority vector in the decision matrix and $a_{i j}$ is the criterion in each column in the matrix.

$$
\begin{gathered}
\lambda_{\max }=8.876804627 \\
\mathrm{CI}=8.87-8 / 7=0.12
\end{gathered}
$$

where, $\mathrm{CI}$ is the consistency index and $n$ is size or order of the matrix, $\left(\lambda_{\max }\right)$ is equivalent to the priority vector in the matrix of decision [11].

The consistency ratio (CR) depends on the dimension of the matrix $(n=8)$ thus, random index value $(\mathrm{RI}=1.41)$ [11]. Table 4 shows the Random inconsistency value RI in several sizes for a matrix [11] [14].

$$
\mathrm{CR}=\mathrm{CI} / \mathrm{RI}
$$

$$
\mathrm{CR}=0.12 / 1.41=0.08
$$

\section{Results and Discussion}

Table 5 shows the matrix of pairwise comparisons with AHP weight. The maximum lambda $\left(\lambda_{\max }\right)=8.87, \mathrm{CI}=0.12$ and $\mathrm{CR}=0.08$. If $\mathrm{CR}$ is less than 0.1 the ratio indicates a reasonable consistency level in the pairwise comparison [15]. The final map shows the suitability index for landfill sites in Dammam which was divided into five categories: unsuitable, low suitability, medium suitability, high suitability and ideal suitability areas [16]. Suitability index with areas for all categories of the AHP methods is shown in Figure 5.

The results of the study showed that some of the criteria achieved a high degree 
Table 4. Random inconsistency indices for various values of (n).

\begin{tabular}{ccccccccccc}
\hline $\mathbf{N}$ & $\mathbf{1}$ & $\mathbf{2}$ & $\mathbf{3}$ & $\mathbf{4}$ & $\mathbf{5}$ & $\mathbf{6}$ & $\mathbf{7}$ & $\mathbf{8}$ & $\mathbf{9}$ & $\mathbf{1 0}$ \\
\hline $\mathrm{RI}$ & 0.00 & 0.00 & 0.58 & 0.9 & 1.12 & 1.24 & 1.32 & 1.41 & 1.46 & 1.49 \\
\hline
\end{tabular}

Table 5. Pairwise comparison matrix with AHP weight.

\begin{tabular}{lccccccccc}
\hline \multicolumn{1}{c}{ Criteria } & $\left(\boldsymbol{x}_{1}\right)$ & $\left(\boldsymbol{x}_{2}\right)$ & $\left(\boldsymbol{x}_{3}\right)$ & $\left(\boldsymbol{x}_{4}\right)$ & $\left(\boldsymbol{x}_{5}\right)$ & $\left(\boldsymbol{x}_{6}\right)$ & $\left(\boldsymbol{x}_{7}\right)$ & $\left(\boldsymbol{x}_{8}\right)$ & Wight \\
\hline Distance from wells $\left(x_{1}\right)$ & 1 & 2 & 2 & 3 & 2 & 3 & 2 & 5 & 0.23 \\
Distance from Urban Areas $\left(x_{2}\right)$ & 0.5 & 1 & 1 & 3 & 1 & 3 & 2 & 5 & 0.16 \\
$\begin{array}{l}\text { Distance from waste generation } \\
\text { sources }\left(x_{3}\right)\end{array}$ & 0.5 & 1 & 1 & 3 & 1 & 3 & 2 & 5 & 0.16 \\
Slope $\left(x_{4}\right)$ & 0.33 & 0.33 & 0.33 & 1 & 3 & 1 & 3 & 3 & 0.12 \\
Groundwater depth $\left(x_{5}\right)$ & 0.5 & 1 & 1 & 0.33 & 1 & 3 & 2 & 5 & 0.13 \\
Permeability $\left(x_{6}\right)$ & 0.33 & 0.33 & 0.33 & 1 & 0.33 & 1 & 3 & 3 & 0.08 \\
Distance from airport $\left(x_{7}\right)$ & 0.5 & 0.5 & 0.5 & 0.33 & 0.5 & 0.33 & 1 & 5 & 0.08 \\
Distance to major highways $\left(x_{8}\right)$ & 0.2 & 0.2 & 0.2 & 0.33 & 0.2 & 0.33 & 0.2 & 1 & 0.03 \\
\hline
\end{tabular}

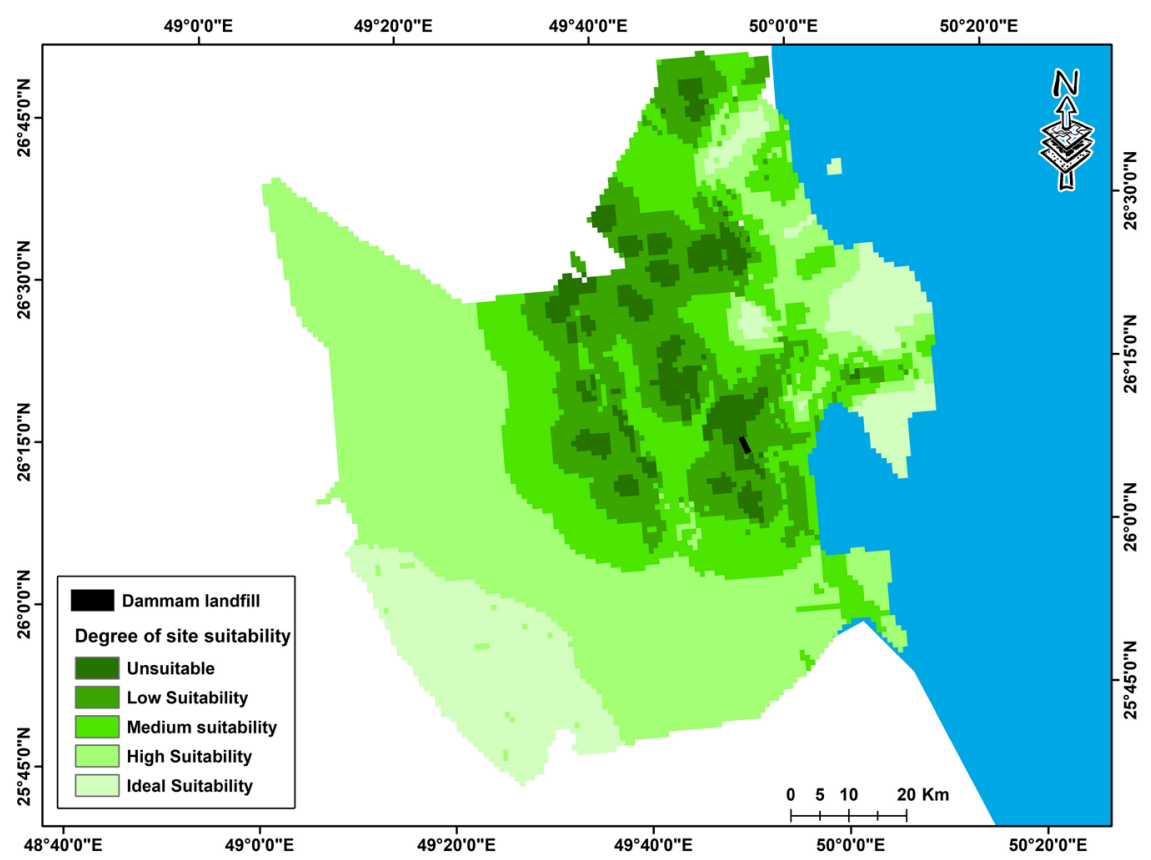

Figure 5. Suitability index area for landfill site using AHP method.

of suitability while some of them were of low suitability. The study investigated 11 criteria, six of which received a high degree of suitability which is flood probability, distance from urban area, distance from airport, and distance from primary highway, slope and the perfect wind direction.

\section{Conclusions}

Multi-criteria decision-making method with the GIS techniques was used to assess the appropriate selection of landfill locations in the studied area. The find- 
ings suggest index values classified into 5 zones with calculated area using GIS pixel calculation. The results show that the high and ideal suitable zone covers the area of $24.35 \%$ and $16.37 \%$ or 591.71 and $392.92 \mathrm{~km}^{2}$ respectively in AHP method.

There are many aspects for researchers to explain and analyze in order to achieve the overall quality standards in their research of which we have covered only a few of them. This study concludes the Dammam's MSW landfill is highly acceptable but the room for improvement is still present especially in the aspect of recycling and maintaining professional municipal solid waste management tactics by experts. This study has been done with a high degree of motivation towards improving the overall quality of the municipal solid waste landfill.

\section{Conflicts of Interest}

The authors declare no conflicts of interest regarding the publication of this paper.

\section{References}

[1] Zhu, D.A., Asnani, P.U., Zurbrugg, C., Anapolsky, S. and Mani, S. (2008) Improving Solid Waste Management in India: A Sourcebook for Policy Makers and Practitioners. World Bank, Washington DC. https://doi.org/10.1596/978-0-8213-7361-3

[2] Basel Convention [WWW Document] (n.d.). http://www.basel.int/TheConvention/Overview/tabid/1271/Default.aspx

[3] Valerio, F. (2010) Environmental Impacts of Post-Consumer Material Managements: Recycling, Biological Treatments, Incineration. Waste Management, 30, 2354-2361. https://doi.org/10.1016/j.wasman.2010.05.014

[4] Robinson, W.D. (1986) The Solid Waste Handbook: A Practical Guide. John Wiley \& Sons, Hoboken. https://doi.org/10.1002/9780470172957

[5] Mundial, B. (2013) Doing Business 2013: Smarter Regulations for Small and Medium-Size Enterprises. The World Bank, Washington DC.

[6] Şener, Ş., Şener, E., Nas, B. and Karagüzel, R. (2010) Combining AHP with GIS for Landfill Site Selection: A Case Study in the Lake Beyşehir Catchment Area (Konya, Turkey). Waste Management, 30, 2037-2046. https://doi.org/10.1016/j.wasman.2010.05.024

[7] Alruhili, O. (2010) The Use of Geographic Information Systems to Determine the Most Appropriate Landfill Sites in Medina.

[8] Khan, D. and Samadder, S.R. (2015) A Simplified Multi-Criteria Evaluation Model for Landfill Site Ranking and Selection Based on AHP and GIS. Journal of Environmental Engineering and Landscape Management, 23, 267-278. https://doi.org/10.3846/16486897.2015.1056741

[9] Simpson, A. and Dandy, G. (1996) Expert System for Water Treatment Plant Operations. Journal of Environmental Engineering, 122, 515-523.

[10] Kara, C. and Doratli, N. (2012) Application of GIS/AHP in Siting Sanitary Landfill: A Case Study in Northern Cyprus. Waste Management \& Research, 30, 966-980. https://doi.org/10.1177/0734242X12453975

[11] Saaty, T.L. and Kearns, K.P. (1985) The Analytic Hierarchy Process. In: Saaty, T.L. and Kearns, K.P., Eds., Analytical Planning, Elsevier, Amsterdam, 19-62. 
https://doi.org/10.1016/B978-0-08-032599-6.50008-8

[12] Teknomo, K. (2006) Analytic Hierarchy Process (AHP) Measuring Business Excellence.

[13] Şener, Ş., Sener, E. and Karagüzel, R. (2011) Solid Waste Disposal Site Selection with GIS and AHP Methodology: A Case Study in Senirkent-Uluborlu (Isparta) Basin, Turkey. Environmental Monitoring and Assessment, 173, 533-554. https://doi.org/10.1007/s10661-010-1403-x

[14] Isalou, A.A., Zamani, V., Shahmoradi, B. and Alizadeh, H. (2013) Landfill Site Selection Using Integrated Fuzzy Logic and Analytic Network Process (F-ANP). Environmental Earth Sciences, 68, 1745-1755.

https://doi.org/10.1007/s12665-012-1865-y

[15] Sólnes, J. (2003) Environmental Quality Indexing of Large Industrial Development Alternatives Using AHP. Environmental Impact Assessment Review, 23, 283-303. https://doi.org/10.1016/S0195-9255(03)00004-0

[16] Uyan, M. (2014) MSW Landfill Site Selection by Combining AHP with GIS for Konya, Turkey. Environmental Earth Sciences, 71, 1629-1639.

https://doi.org/10.1007/s12665-013-2567-9 


\section{Appendix 1}

Table A1. Layers buffer zone with sub-criteria ratings.

\begin{tabular}{|c|c|c|}
\hline Criteria & Sub-Criteria and Buffer Zone & Rating Values \\
\hline \multirow{7}{*}{ Groundwater depth (m) } & $<10$ & 0 \\
\hline & $10-25$ & 1 \\
\hline & $25-35$ & 2 \\
\hline & $35-70$ & 3 \\
\hline & $70-100$ & 4 \\
\hline & $100-200$ & 5 \\
\hline & $>200$ & 6 \\
\hline \multirow{7}{*}{ Distance from wells (km) } & $<2$ & 0 \\
\hline & $2-4$ & 1 \\
\hline & $4-6$ & 2 \\
\hline & $6-8$ & 3 \\
\hline & $8-14$ & 4 \\
\hline & $14-25$ & 5 \\
\hline & $>25$ & 6 \\
\hline \multirow{7}{*}{ Distance from Urban areas (m) } & $<500$ & 0 \\
\hline & $500-1500$ & 1 \\
\hline & $1500-2500$ & 2 \\
\hline & $2500-3500$ & 3 \\
\hline & $3500-4500$ & 4 \\
\hline & $4500-8500$ & 5 \\
\hline & $>8500$ & 6 \\
\hline \multirow{7}{*}{ Distance from airports (m) } & $<1500$ & 0 \\
\hline & $1500-3000$ & 1 \\
\hline & $3000-4500$ & 2 \\
\hline & $4500-5500$ & 3 \\
\hline & $5500-7500$ & 4 \\
\hline & $7500-11,500$ & 5 \\
\hline & $>11,500$ & 6 \\
\hline \multirow{7}{*}{$\begin{array}{l}\text { Distance from waste generation sources } \\
\qquad(\mathrm{km})\end{array}$} & $>30$ & 0 \\
\hline & $20-30$ & 1 \\
\hline & $15-20$ & 2 \\
\hline & $10-15$ & 3 \\
\hline & $8-10$ & 4 \\
\hline & $5-8$ & 5 \\
\hline & $<3$ & 6 \\
\hline
\end{tabular}




\section{Continued}

\begin{tabular}{|c|c|c|}
\hline \multirow{4}{*}{ Distance to Primary Highways (m) } & $<168$ & 0 \\
\hline & $168-336$ & 1 \\
\hline & $336-500$ & 3 \\
\hline & $>500$ & 6 \\
\hline \multirow{7}{*}{ Permeability (liter/day/m²) } & $<24$ & 0 \\
\hline & $24-12$ & 1 \\
\hline & $12-8$ & 2 \\
\hline & $8-2$ & 3 \\
\hline & $2-0.75$ & 4 \\
\hline & $0.75-0.5$ & 5 \\
\hline & $0.5-0.25$ & 6 \\
\hline \multirow{7}{*}{ Slope (\%) } & $<0.5$ & 0 \\
\hline & 0.6 & 1 \\
\hline & 0.7 & 2 \\
\hline & 0.9 & 3 \\
\hline & 1.1 & 4 \\
\hline & 1.2 & 5 \\
\hline & 1.5 & 6 \\
\hline
\end{tabular}

